\title{
The Structural Shortcomings of INEE: An Intersectional Perspective on Young Women of Afghanistan
}

\author{
Ahmed Alameldeen ${ }^{*}$, Saba Fatima ${ }^{2}$ \\ ${ }^{1}$ Department of Health Sciences, University of York, York, UK \\ ${ }^{2}$ Department of Cultural Studies, National College of Arts, Lahore, Pakistan \\ Email: *ahmed.alameldeen@alumni.york.ac.uk
}

How to cite this paper: Alameldeen, A., \& Fatima, S. (2021). The Structural Shortcomings of INEE: An Intersectional Perspective on Young Women of Afghanistan. Open Journal of Social Sciences, 9, 78-84. https://doi.org/10.4236/jss.2021.910005

Received: September 25, 2021

Accepted: October 16, 2021

Published: October 19, 2021

Copyright $\odot 2021$ by author(s) and Scientific Research Publishing Inc. This work is licensed under the Creative Commons Attribution International License (CC BY 4.0).

http://creativecommons.org/licenses/by/4.0/

\begin{abstract}
Given the gender-inequality index regarding education in the backdrop of protracted conflicts, the narrow "Education in Emergency" paradigm observed by the Inter-Agency Network for Education in Emergencies (INEE) provides the evidence for institutional and policy failure to understand the structural intricacies as well as socio-political temporalities in a contextual manner (Shuayb, 2018). INEE's drafts for the educational policies designed amidst the conflict without a sound epistemological approach give the impression that the definition of their progress and sustainability is reduced to mere statistical data. The theoretical conceptualizations seem to be apolitical and don't use a contextual and intersectional feminist lens producing a wide longitudinal research gap. This study intends to explore these research gaps in the policy frame analysis of INEE through a gendered lens and contextualizes the case study of Afghanistan. It hypothesizes that the de-politicization, exclusiveness, repatriation, and short-term vision of INEE policies are responsible for not achieving the desired results. A comprehensive consideration and mapping of geopolitical and biopolitical realities of Afghan women along with a structural understanding of socio-cultural realities, however, might lead to the better drafting of educational policies for women during the conflict and crisis.
\end{abstract}

\section{Keywords}

Education in Emergency, INEE, Afghan Women, Intersectionality, Refugees

\section{Introduction}

According to one estimate, the number of out of school children in Afghanistan 
is about 3.7 million of which $60 \%$ are girls (UNICEF 2020). This percentage is likely to increase given the anti-women policies of Taliban after they took over in August, 2021 (Maizland, 2021). Banning girls from attending secondary schools has already been announced by the new government implying that there are rare chances for them to get higher education (Guardian, 2021). Amidst this situation, the international organizations are investing to improve the statistics along different indices. In this context, Inter-Agency Network for Education in Emergencies (INEE) conceptualized in 2000 at World Education Forum with the collaboration of different donors, international organizations (IGOs), and non-governmental organizations (NGOs) is a significant avenue. INEE's guiding principles are directed to meet the Minimum Standards for Education during the humanitarian crises that include the natural calamities as well as conflict situations (INEE, 2021). Although INEE has specified the agenda for women education during the emergency situation, it fails to situate the particular contextual nature of the humanitarian crisis and caters it in a very bureaucratic manner. Afghanistan presents such an interesting case study where the functionality of these policies is challenged. The supporting arguments in this context will be provided while underpinning the research and policy gaps of INEE in the upcoming discussion. The Taliban regime, refugee crisis, and the geopolitics of the region blended with the efforts made by INEE to provide the luxury of education to women living in highly patriarchal and fundamentalist environment are just to mention a few posed challenges. The underlying reason for these challenges originates from a failure to develop a micro-level structural understanding of Afghan women, and the attributed socio-political realities. In this context, structural delimitations of INEE's Minimum Standards for Education have been investigated via debate on a few underscored research gaps within the context of education provision.

\section{The Apolitical Approach of INEE}

This section focuses on the apolitical mechanism that INEE adopts to deal with the situation that is highly political. The "political", here, implies an understanding of the operationalization of the political institutions at different analytical levels. It is pertinent to mention that INEE maps its policies in a uniform way for all types of crises that might be natural calamities or political conflicts whether militant or non-militant. For instance, the guiding principles of INEE have commitment towards an adherence to the global commitment without corresponding to regional and indigenous subjectivities based on the generalization of all crises-struck populations. However, the nature of emergencies and the challenges faced in crisis situations are very contextual. For example, the case study of women's education in the aftermath of earthquake in Haiti (Rivera, 2012) is very different from the women of Afghanistan living under the Taliban regime. In Haiti Plan by INEE, community participation was ensured, and professional teachers were hired to improve access to schools and non-formal edu- 
cation even for the disabled children (Rivera, 2012). If same mechanism is implemented for providing education to Afghan girls, it simply cannot work. With Taliban in power position, the spatial segregation of genders is the first challenge followed by their narrow cognitive approach towards women's education and their liberty to work in professional fields. For example, after Taliban takeover in August, their new policies reinforced the gender binaries by segregating the classrooms for boys and girls (Associated Press, 2021), banning girls from going to secondary schools, (Guardian, 2021) and replacement of foreign ministry with "guidance ministry" leading to the formulation of government only by men (Aljazeera, 2021). The drafting of uniform proposals without a contextual political understanding, thus cannot work effectively for educating the women in emergency situations.

Another significant aspect is the geopolitical understanding of the crisis and framing of the related problem in that situation. In case of Afghanistan, the biggest chunk of population from underprivileged economic class as a subject of conflict and oppression migrated to Pakistan. How INEE caters these migrants is another important question. A gendered perspective of these migrants then involves more intricacies given the fact that the new geographical realities are patriarchal in essence that are further manipulated with destitution and poor handling. In this type of crisis situation, the treatment of INEE towards Afghan women in Pakistan cannot be the same as that in the Haiti Plan and demand a deeper structural and political understanding to respond effectively.

\section{Intersectional Feminism and Provision of Education during Emergency Situation}

Professor Kimberlé Crenshaw, who is the founder of the theory of intersectionality challenged the single axis framework towards the problem of oppression and discrimination. She pitched in the idea of intersectionality by arguing that oppression and violence are multi-axial implying that a woman is likely to face discrimination on the basis of her class, gender, and race simultaneously. This idea of intersectionality gained currency in the feminist discourse during the third wave of feminism. According to Crenshaw "when there's no name for a problem, you can't see a problem and when you can't see a problem; there's no way you can solve it" (Crenshaw, 1989). Using this intersectional lens, it can be argued that all the Afghan women as a subject of conflict cannot be taken as one unit to be dealt with uniform policy framework rather, they face different typologies of discrimination and hence need different approaches for solution. For instance, in the Afghan social structure, the Hazara women are oppressed doubly based on their race and gender and the discrimination against them is more likely to be reinforced by the state institutions and other colonial legacies (Saikal, 2012). Taking into account the conflict situation in Afghanistan where Taliban are in power position and occupying the state institutions, the chances for this intersectional oppression are enhanced. This intersectionality is also considerate 
of the class system and the domestic structure of Afghan households. A woman belonging to low-income household is more likely to either stay in Afghanistan under the Taliban regime or in case of migration, she might end up in a Pakistani refugee camp. On the other hand, for a woman of high-income family, the likely chance is to migrate to a Western developed state. The response mechanism of INEE towards women from these two different economic backgrounds cannot be same and if that is the case, INEE's response might be a failure. For example, none of the nineteen standards of the INEE accompanied with their "key actions and guidance notes" involves a mechanism to conduct a comprehensive research before application of their policies (INEE, 2021). This argument can be supported by digging deeper into the structural complexities in case of Afghanistan. A refugee woman in Pakistan who is already a subject of conflict and economic crisis is more likely to focus on her survival rather than pursuing education that might seem a luxury. In Afghanistan's case, this chance is most probable because of the protracted nature of the conflict. Here, INEE disregards the bio-segregated space of the educational receptionist context (Shuayb, 2018). Fassin criticizes the "humanitarian reason" by putting emphasis on the fact that more attention is paid to biography rather than biological life. According to her, "Humanitarian reason pays more attention to the biological life of the destitute and unfortunate, the life in the name of which they are given aid, than to their biographical life, the life through which they could, independently, give a meaning to their own existence" (Fassin, 2011).

On the parallel lines, the experience of an Afghan woman with a better economic background who migrated to a developed country, there is a better chance of survival, availing tutors or formal education and even benefitting from the policies of INEE. However, even in this case, the situation might be challenging depending on the strength of structural and heteronormative patriarchy in the household that might hinder the education availability for women. The policy framework adopted by INEE doesn't seem to cope with such contextual challenges regarding the education for Afghan women implying the diminished epistemologies in its structural element.

\section{Repatriation Policies of INEE}

A report published by INEE in 2004 says: "for refugees, it is preferred to adopt the curricula of the country of origin to facilitate voluntary repatriation" (Shuayb, 2018). This policy can be very problematic in case of Afghanistan. According to one report, 1.4 million Afghan refugees are hosted by Pakistan (UNHCR, 2018) who migrated between 1979 and 1989 during the Afghan war and this influx has continued with different transitions since then. The Refugees Education Program (REP) that started in International Rescue Committee (IRC) in 1992 drafted its agenda to provide education to the Afghan refugees in Khyber Pakhtunkhwa (KP) province of Pakistan. Later, this program was handed over to Participatory Rural Development Society (PRDS), a National NGO on October 
1, 2010, that used the INEE Foundational Standards of Community Participation and Resources. The schools operating under this program implemented the official Afghan Curriculum and followed Afghan MoE policies, rules, and regulations (Nazli, 2011). The underlying reason for this policy mechanism is based on the understanding that following related curriculum can ease the process of repatriation. In case of Afghanistan, the institutions and curriculums influenced by the prevalent structural norms, attitudes, and behaviors in the society are colonized with the fundamentalist notions serving the interests of power groups. Globally, the coloniality of power is retained by the epistemic coloniality as Quijano suggests, then how is it possible for the domestic and native colonialization to not retain the respective interests (Quijano, 2000). While implementing the repatriation policies, INEE needs to keenly consider this epistemic coloniality existing in the academic infrastructure and act in a contextual manner. The curriculum and the institutions are fundamental in mapping the cognitive framework of the students, thus defining the future events. In the wake of return of Taliban's power, the question that can be posed to INEE policy makers is if curriculum designed by Afghanistan's education ministry in control of Taliban applicable to Afghan refugees and if yes, then what are the implications for refugee women in the backdrop of resultant changing geopolitics. These arguments imply that the repatriation policies of INEE can inflict more damage to Afghan women's education than doing any good.

Another policy drawback can be evidenced from the observation that Afghan children who got education as per repatriation policies of INEE have very fewer job prospects as compared to the children who studied in Pakistani schools (Shuayb, 2018). These job prospects become bleaker for women in the patriarchal setup and curriculum acts as one of the major hurdles against advanced education.

\section{Short-Term Vision of INEE}

INEE aims to provide education during the emergency situations without considering the protracted nature of the conflicts. A natural calamity and a conflict in Afghanistan cannot be compared on the parallel lines given the fact that challenges in both situations are totally different. Maha Shuyab argues that a lack of coherent policies and a strategic vision in the long term does not make it a sustainable program leading to a lack of imagination for future incentives that education can bring (Shuayb, 2018). It is a matter of question that why an Afghan women refugee would be sent off to school when there is no visible incentive for education. It is more sustainable for a refugee family to either marry her off or to use her as a free labor. How INEE deals with the education of these young married women and young workers leads to another policy critique. The lack of status of the citizen or the refugee in the interplay of biopolitics has also implications on the women's education. How INEE deals with such biopolitical issues to ensure the education for these women is another question that INEE guidelines 
fail to answer giving the impression that the policy provisions of the organization are missing on long-term goals.

\section{Conclusion}

To conclude the critique, it can be argued that a wide longitudinal research gap exists in the INEE policy framework challenging its notions of social justice. Nancy Fraser redefines justice in her work "Social Justice in the Age of Identity Politics: redistribution, recognition and participation" by arguing that social justice cannot be measured merely based on redistribution of wealth rather it needs to be considerate of other factors such as multi-culturalism, identity politics, redistribution, and recognition. The recognition of an individual as a refugee and the specific curriculum designing for him/her implies a sense of exclusion from the rest of the social fabric. This recognition leads to the redistribution of epistemic resources that are not based on the principles of parity. A lack of this understanding is the reason for policy failures of INEE. This has serious socio-political implications. For example, in the case of Afghanistan, the young women who're married off without any education might face not only health issues giving birth to weak children but they might also face the financial dependence that in turn gives incentive to the patriarchal structure of the society. The population of women in Afghanistan is almost half that of men and depriving them education and eventually job opportunities mean, a huge loss to the national economy and ultimately a political chaos. Lack of education might also keep the Afghan women away from the politics without developing a sense of historical imagination that might, ultimately, lead to their political marginalization giving more power in the hands of Taliban men. However, if the pre-requisite of diving deep into the structural intricacies of the geography in emergency situation is fulfilled, the policy gaps of INEE can be bridged. A proper flexible committee for each emerging and evolving conflict can be designed by INEE to formulate policies after they're being informed by the members working at micro-level. Although INEE claims to ensure community participation, it needs to work in the transparency mechanism while keeping in mind the power politics of the local tribes and their leaders. INEE also needs to diversify its definition of "emergency" because the conflict situation that sometimes might also be protracted is much different from the natural calamity. Moreover, a deep and intersectional understanding of the indigenous culture is needed rather than just relying on the colonial epistemic generalizations regarding Orient and Occident. The policies should be devised after a structural and contextual understanding of the socio-political realities of the region in emergency situation. INEE as an established organization can contribute a lot more to the provision of education by identifying and bridging the policy gaps.

\section{Conflicts of Interest}

The authors declare no conflicts of interest regarding the publication of this paper. 


\section{References}

Aljazeera (2021). Taliban Replaces Ministry for Women with “Guidance” Ministry. https://paste.pics/c4e40ab136ac6a4509fc9902ae31ba48

Associated Press (2021). The Taliban Say That Women Can Study in Gender-Segregated Universities.

https://www.npr.org/2021/09/12/1036485673/taliban-rule-afghanistan-women-gendersegregated-universities

Crenshaw, K. (1989). Demarginalizing the Intersection of Race and Sex: A Black Feminist Critique of Antidiscrimination Doctrine, Feminist Theory and Antiracist Politics. The University of Chicago Legal Forum, 1, 139-167.

Fassin, D. (2011). Humanitarian Reason: A Moral History of the Present (Translated by Rachel Gomme). University of California Press. https://doi.org/10.1525/california/9780520271166.001.0001

Guardian (2021). Taliban Ban Girls from Secondary Education in Afghanistan. Guardian. https://www.theguardian.com/world/2021/sep/17/taliban-ban-girls-from-secondary-ed ucation-in-afghanistan

INEE (2021). Inter-Agency Network for Education in Emergencies (INEE). https://inee.org/about-inee

Maizland, L. (2021). Backgrounder: The Taliban in Afghanistan. Council on Foreign Relations. https://paste.pics/d97504bd1f131f0789a8b204b840652b

Nazli, F. (2011). INEE Minimum Standards Case Study: Responding to Afghan Refugees in Pakistan. INEE. https://inee.org/system/files/resources/Case study pakistan_PRDS.pdf

Quijano, A. (2000). Coloniality of Power and Eurocentrism in Latin America. International Sociology, 15, 215-232. https://doi.org/10.1177/0268580900015002005

Rivera, C. (2012). INEE Minimum Standards Case Study. INEE. https://inee.org/resources/inee-minimum-standards-case-study-non-formal-education -haiti

Saikal, A. (2012). Afghanistan: The Status of the Shi'ite Hazara Minority. Journal of Muslim Minority Affairs, 32, 80-87. https://doi.org/10.1080/13602004.2012.665623

Shuayb, M. (2018). A Critique of Education in Emergency and Humanitarian Contexts: Observations from the Field. In C. Kyriakides, \& R. D. Torres (Eds.), Borders of Mass Destruction: Refugees, Racialization and National Belonging (pp. 1-20). Routledge.

https://www.researchgate.net/profile/Maha-Shuayb-2/publication/333747718 A Critiq ue of Education in Emergency and Humanitarian Contexts Observations from th e field/links/5d020b12299bf13a38511e16/A-Critique-of-Education-in-Emergency-and -Humanitarian-Contex

UNHCR (2018). UNHCR: Pakistan. https://www.unhcr.org/pakistan.html

UNICEF (2020). UNICEF Education for Everyone: Afghanistan. UNICEF. https://www.unicef.org/afghanistan/education 